\title{
La Saga de Tristán e Iseo
}

Álfrún GunNLAUGSDótTIR (ed. y trad.) (2019). Madrid, Editorial Miraguano, 231 páginas. ISBN 978-84-7813-481-6.

\section{Kaila Yankelevich \\ kailayankelevich@gmail.com.ar \\ Instituto de Filología y Literaturas Hispánicas “Dr. Amado Alonso”, Facultad de Filosofía y Letras, Universidad de Buenos Aires, Argentina}

La leyenda de Tristán e Iseo constituye una de las historias de amor más influyentes dentro del imaginario occidental. De origen incierto, aunque de posible procedencia celta, el relato fue fijado en numerosas versiones tanto en la Edad Media como en los siglos que le siguieron; de las reescrituras recientes, la más renombrada es probablemente la ópera de Richard Wagner, Tristan und Isolde. A pesar de la popularidad de este trágico relato de amor adúltero, que atraviesa épocas y espacios geográficos diversos, las versiones medievales más tempranas han llegado a nosotros en un estado fragmentario. Estas son dos versiones anglonormandas en verso que datan del siglo XII: la de Béroul, que se conserva incompleta en un único manuscrito, y la de Thomas de Inglaterra, que se halla segmentada en nueve fragmentos discontinuos, el último de los cuales fue descubierto en 1995 (Lupack, 2007: 374). Estos segmentos presentan solo una pequeña parte de la extensa obra que debió de haber sido en el pasado. Ambas versiones sirvieron como base para el desarrollo posterior de dos tradiciones de reescrituras de la leyenda: la "popular", derivada del roman de Béroul, y la "cortés", que abreva en el de Thomas (Frappier, 1963), fuente de la inconclusa recreación de Gottfried von Strassburg, obra de comienzos del siglo XIII en la que se inspiró la ópera de Wagner.

En este contexto, resulta especialmente relevante la existencia de la Saga af Tristram ok Ísönd o Saga de Tristán e Iseo. Esta versión nórdica del relato fue compuesta en Noruega hacia el año 1226, durante el reinado de Hákon Hákonarson, quien hizo de la revitalización de la cultura nórdica parte central de su proyecto político. Según su propio autor (el hermano Robert, de quien no se conoce más que el nombre), la saga es una traducción de una fuente identificada como Le roman de Tristan, la obra perdida de Thomas. Así, esta versión permite conocer y reconstruir, aunque de manera indirecta e hipotética, una de las puestas por escrito más antiguas de la leyenda.

En este volumen, la autora, Álfrún Gunnlaugsdóttir, presenta una actualización de la traducción que realizó para su tesis doctoral de la Saga af Tristram ok Ísönd hace casi cincuenta años, y que publicó por primera vez en Islandia en 1978. La traducción del noruego medieval, idioma que hoy en día es más legible para los islandeses que para los mismos noruegos, se presenta por primera vez de manera accesible en español y pone al alcance de un nuevo grupo de lectores la vertiente nórdica de una historia que ha sido revisada y reescrita muchas veces a lo largo de los siglos.

El libro propiamente dicho, publicado por la editorial Miraguano, contiene una "Introducción" y la traducción de la Saga. La "Introducción”, redactada en el español particular de Gunnlaugsdóttir (debajo del cual se adivinan otras lenguas), contiene información necesaria que permite comprender y situar mejor la saga. Para tal fin, la autora examina el origen medieval del texto, el contexto cultural de su producción (un período en el que los intelectuales noruegos solían realizar viajes de estudio a Francia, de donde quizás el fraile Robert importó el poema de Thomas), su tradición manuscrita y el caso especial que supone la llegada tardía de la imprenta a Islandia, donde se la adoptó recién en el siglo XVI. Además, se comentan algunas de las decisiones tomadas por el traductor medieval, cuyo trabajo Gunnlaugsdóttir defiende de la etiqueta de "mecánico" que a veces le ha puesto la crítica: por ejemplo, se destaca su modo de narrar, que tiende a la objetividad, el hecho de que no busque guiar al lector como hacía Thomas, y que elimine algunos largos soliloquios presentes en el poema anglonormando. Finalmente, se especifican algunos criterios que se han seguido en la traducción del texto noruego al español. El trabajo final incluye, solo cuando es necesario, unas pocas notas al pie, es fácil de leer y permite al lector introducirse sin esfuerzo en el relato.

Por estos motivos, la edición es accesible para aquel lector poco familiarizado con escritos medievales que desee incursionar en esta literatura. Esto no la hace menos valiosa, sin embargo, para la investigación académica, debido al cuidado con el que ha 
sido realizada y a la posibilidad única que provee de estudiar un texto que, por el idioma en el que fue concebido en sus orígenes, resultaba hasta ahora poco conocido para el público hispanohablante. Además, el surgimiento de nuevo material de esta índole resulta sobre todo relevante en el ámbito académico hispanohablante donde, según observa González Campo (2010: 121), se registra históricamente una falta de interés por el estudio de las producciones literarias de la Escandinavia medieval.

Un elemento destacable de la edición lo constituye la separata que acompaña el volumen principal, con un título que alude a la tesis doctoral de la autora: "Tristán en el Norte. Una visión personal y académica". En este apartado se introducen dos series de reflexiones personales de la autora divididas en sendos capítulos. En el primero, Gunnlaugsdóttir hace un recorrido por su vida profesional, que comenzó en Islandia y la llevó a transitar por la España franquista primero y por Suiza después, para luego de muchos años devolverla, ya con su tesis terminada, a su país natal, donde comenzó a dar clases y a escribir libros de ficción. La autora medita en torno al tema fundamental de las lenguas y la traducción, que en una edición de estas características se reviste de una importancia obvia, y su influencia en la vida personal, cultural y académica de quienes leemos y estudiamos literatura. En el segundo capítulo, Gunnlaugsdóttir se centra en la saga de Tristán e Iseo y, en particular, en el que considera su tema central y motor del relato: el amor.

\section{Bibliografía}

» Frappier, J. (1963). "Structure et sens du Tristan : version commune, version courtoise". Cahiers de civilisation médiévale, Nro. 23, 255-280.

» González Campo, M. (2010). “Bibliographia Normanno-Arturica. Textos y estudios sobre la traducción y adaptación de la literatura artúrica en la Escandinavia medieval". Hermēneus. Revista de Traducción e Interpretación, Nro. 12, 121-145.

» Lupack, A. (2007). The Oxford Guide to Arthurian Literature and Legend. Nueva York: Oxford University Press. 